The Journal of Laryngology \& Otology

http://journals.cambridge.org/JLO

Additional services for The Journal of Laryngology \& Otology:

Email alerts: $\underline{\text { Click here }}$

Subscriptions: $\underline{\text { Click here }}$

Commercial reprints: Click here

Terms of use : $\underline{\text { Click here }}$

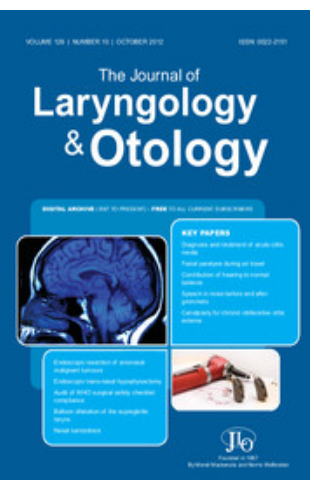

\title{
Parotid haemangiomas in childhood: a case for MRI
}

Philippa Huchzermeyer, M. A. Birchall, B. Kendall and C. M. Bailey

The Journal of Laryngology \& Otology / Volume 108 / Issue 10 / October 1994, pp 892 - 895

DOI: 10.1017/S0022215100128439, Published online: 29 June 2007

Link to this article: http://journals.cambridge.org/abstract_S0022215100128439

How to cite this article:

Philippa Huchzermeyer, M. A. Birchall, B. Kendall and C. M. Bailey (1994). Parotid haemangiomas in childhood: a case for MRI. The Journal of Laryngology \& Otology, 108, pp 892-895 doi:10.1017/S0022215100128439

Request Permissions : $\underline{\text { Click here }}$ 


\title{
Radiology in Focus
}

\section{Parotid haemangiomas in childhood: a case for MRI}

\author{
Philippa Huch7ermeyer, M.A. Birchall, B. Kendall*, C. M. Bailey
}

\begin{abstract}
Seven infants with unilateral parotid haemangiomas seen at one centre are presented. Their case notes and special investigations are reviewed. Magnetic resonance imaging (MRI) is revealed as the investigation of choice because of picture quality, definition of soft tissues and lack of exposure to ionizing radiation. MRI allows a definite diagnosis to be made without any invasive procedure being required. A future study following up these infants may be of interest because of controversy regarding the spontaneous resolution of these lesions.
\end{abstract}

Key words: Parotid neoplasms; Haemangioma; Magnetic resonance imaging

\section{Introduction}

Although noninfective parotid swellings are uncommon, parotid haemangiomas account for perhaps 20 per cent of all parotid tumours and 50 per cent of those presenting in the first year of life. We present a series of seven patients with this condition seen at one centre over a two-year period. Diagnosis is made on a combination of clinical and radiological findings and these are discussed. In many cases the lesions undergo spontaneous involution. It is therefore particularly important that they are accurately diagnosed and that no unnecessary or potentially harmful diagnostic or therapeutic procedures are carried out. The aim of this study was to examine how best to establish a diagnosis.

\section{Methods}

The case notes of seven patients with parotid haemangiomas presenting to the Otolaryngology Department, The Hospital for Sick Children, Great Ormond Street, in the period April 1991 to April 1993 were reviewed retrospectively. All radiological investigations including ultrasound, computerized tomographical scans (CT) and magnetic resonance imaging (MRI) were critically reassessed and compared. Ultrasound scans (US) were performed on awake patients while CT scans and MRI were performed under sedation as day cases.

\section{Results}

The patient data is summarized in Table I.

\section{Patterns of presentation}

Six female infants and one male infant presented, at under 15 months of age, with a unilateral, soft swelling over the angle of the jaw that was gradually increasing in size (Figure 1). The swellings were all noticed before the age of six months but none were present at birth. Three of the seven infants had cutaneuos haemangiomas at the other sites (forehead, neck, groin, chin, shoulder). There were no serious illnesses or congenital abnormalities present

\section{Clinical findings}

Clinically the haemangiomas manifest as nontender, unilateral, soft swellings over the angle of the jaw. The swelling fills and becomes tense on crying. Two of the seven patients had a bluish discolouration of the skin overlying the haemangioma. There were no cardiovascular disturbances and no bruits heard over the lesions.

The period of follow-up varied between 0 and two years. The two infants followed up for two years showed a decrease in haemangioma size on sequential clinical assessment by the same surgeon.

\section{Ultrasound investigation}

Ultrasound of the parotid swellings revealed a lobulated swelling in the parotid region and in some showed pulsation or a pulsating enlarged feeding vessel. However usually no firm diagnosis could be made at the time of investigation.

\section{CT scan investigation}

Three patients were investigated by CT scan. This showed the lesion as a circumscribed mass in the parotid which enhanced with intravenous contrast. A representative view is shown in Figure 2.

\section{MRI investigation}

Six patients were investigated by MRI. Analysis of these MRIs showed several common features. All the lesions were dark on $T_{1}$-weighted images, with a signal intensity similar to that of grey matter and a lower signal intensity than normal par-

From the Departments of Paediatric Otolaryngology and Radiology*, The Hospital for Sick Children, Great Ormond Street, London WCIN 3JH.

Presented at the 1993 meeting of the British Association of Paediatic Otolaryngology on 11 June, 1994.

Accepted for publication: 15 January 1994. 
TABLE I

SUMMARY OF CLINICAL FINDINGS AND INVESTIGATIONS

\begin{tabular}{|c|c|c|c|c|c|c|}
\hline $\begin{array}{l}\text { Case } \\
\text { no. }\end{array}$ & $\begin{array}{l}\text { Age at } \\
\text { onset }\end{array}$ & $\begin{array}{l}\text { Age at } \\
\text { presentation }\end{array}$ & Sex & Description & Investigation & Follow-up \\
\hline 1 & 5 weeks & 2 months & $\mathrm{F}$ & $\begin{array}{l}\text { Left parotid swelling and } \\
\text { cutaneous haemangioma on } \\
\text { chin }\end{array}$ & $\begin{array}{l}\text { CT: circumscribed enhancing } \\
\text { mass in left parotid }\end{array}$ & No change over 14 months \\
\hline 2 & 3 months & 9 months & $\mathrm{F}$ & $\begin{array}{l}\text { Right parotid swelling about } \\
2 \mathrm{~cm} \text { in diameter }\end{array}$ & $\begin{array}{l}\text { US: mass supplied by large } \\
\text { vessel. } \\
\text { MRI: lobulated mass with low } \\
\text { signal regions (vessels) }\end{array}$ & No change in 2 months \\
\hline 3 & 2 months & 5 months & $\mathrm{F}$ & $\begin{array}{l}\text { Right parotid swelling and } \\
\text { cutaneous haemangioma of } \\
\text { forehead, neck and groin }\end{array}$ & $\begin{array}{l}\text { US: lobulated mass, diagnosis } \\
\text { impossible. } \\
\text { MRI: lobulated mass with } \\
\text { normal parotid tissue } \\
\text { compressed, several regions of } \\
\text { signal void (vessels) }\end{array}$ & $\begin{array}{l}\text { Reducing in size over } 15 \\
\text { months }\end{array}$ \\
\hline 4 & 2 months & 3 months & $\mathbf{M}$ & $\begin{array}{l}\text { Right parotid swelling about } \\
3 \times 4 \mathrm{~cm} \text { in size }\end{array}$ & $\begin{array}{l}\text { US: pulsatile mass. } \\
\text { MRI: large parotid } \\
\text { haemangioma extending } \\
\text { around great vessels and into } \\
\text { parapharyngeal region }\end{array}$ & $\begin{array}{l}\text { Reducing in size over } 18 \\
\text { months }\end{array}$ \\
\hline 5 & 3 weeks & 3 months & $\mathrm{F}$ & $\begin{array}{l}\text { Right parotid swelling ill- } \\
\text { defined, extending into neck }\end{array}$ & $\begin{array}{l}\text { US: mass of vascular origin. } \\
\text { MRI: large haemangioma of } \\
\text { parotid fed by hypertrophied } \\
\text { facial artery }\end{array}$ & $\begin{array}{l}\text { Follow-up at local hospital } \\
\text { 'fluctuates in size' }\end{array}$ \\
\hline 6 & 2 months & 14 months & $\mathrm{F}$ & $\begin{array}{l}\text { Right parotid swelling, } 5 \mathrm{~cm} \\
\text { in diameter with blue colour } \\
\text { on crying and cutaneous } \\
\text { haemangioma of left shoulder }\end{array}$ & $\begin{array}{l}\text { US: vascular lesion. } \\
\text { MRI: lobulated mass with } \\
\text { signal voids }\end{array}$ & No follow-up data yet \\
\hline 7 & 5 months & 10 months & $\mathrm{F}$ & $\begin{array}{l}\text { Right parotid swelling with } \\
\text { central red-blue discolouration }\end{array}$ & $\begin{array}{l}\text { MRI: lobulated lesion with } \\
\text { signal void areas }\end{array}$ & No follow-up data yet. \\
\hline
\end{tabular}

otid (Figure 3). On $\mathrm{T}_{2}$-weighted images the haemangioma appeared bright, with a high signal intensity similar to cerebrospinal fluid (Figure 4). The shape of the haemangioma was lobulated in appearance and within the lesions were regions of low signal consistent with flow voids representing blood vessels. Some views showed septae of high signal on both $T_{1}$ and $T_{2}$ weighted sequences.

\section{Discussion}

Salivary gland tumours are rare in children and the frequency of the various histological types found differs from that of adult patients. Working out incidences from the reported literature

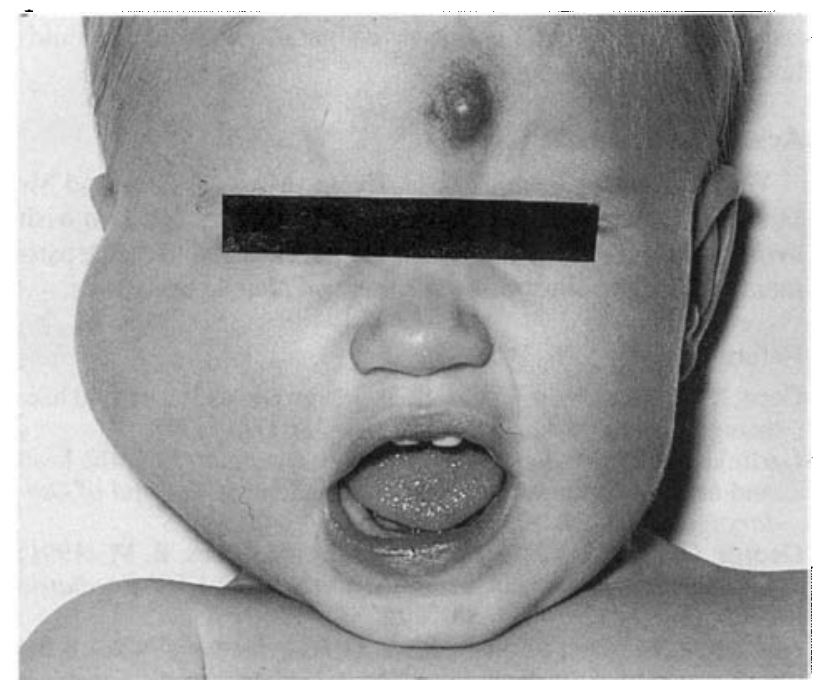

Fig. 1

Right parotid haemangioma and associated cutaneous haemangioma in a 10-month-old infant girl. brings with it the problem that infective and other benign lesions are under reported as they do not present to a surgeon or pathologist. Some authors estimate that parotid haemangiomas account for 50 per cent of parotid tumours presenting in the first year of life (Garfinkle and Handler, 1990).

A differential diagnosis has to consider infective lesions, hamartomas and neoplasms. The diagnosis of an infective lesion is usually easily made with typical features being pain and systemic upset. Suspicion of a hamartoma or tumour makes further investigation mandatory. The hamartomas include haemangioma, lymphangioma (cystic hygroma) and neurofibroma

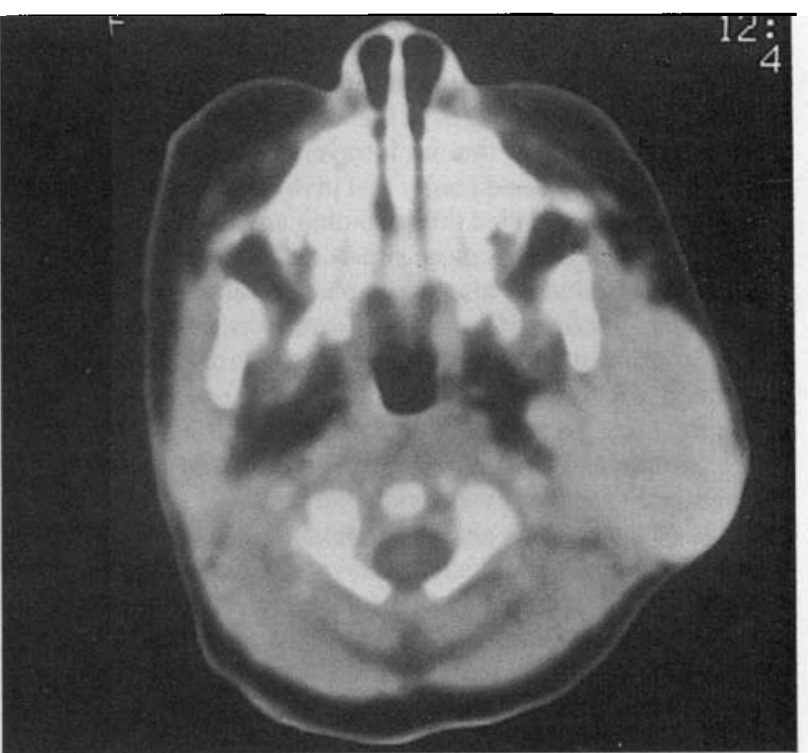

FIG. 2

CT scan showing an enhanced mass in the left parotid representing a haemangioma. 


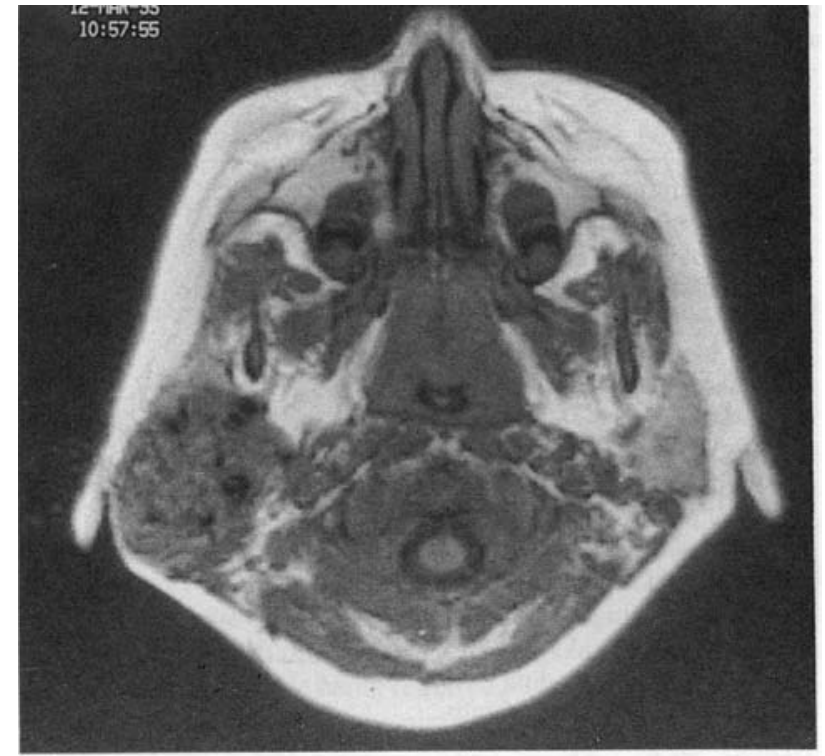

FIG. 3

MRI scan, $T_{1}$-weighted image, showing a right parotid haemangioma with an image intensity similar to that of grey matter.

Clinically both haemangioma and lymphanioma may present as unilateral, soft and possibly fluctuant swellings. On investigation with MRI the most important differentiating feature between lymphangiomas and haemangiomas is that signal voids representing blood vessels are absent in lymphangiomas. In addition lymphangiomas of the parotid are rare as they most commonly arise from the posterior triangle of the neck and may secondarily involve the salivary glands (Stenson et al., 1991).

The MRI appearance of childhood parotid haemangiomas is characteristic showing a dark lesion on $\mathrm{T}_{1}$ - and a bright lesion on $\mathrm{T}_{2}$-weighted images. In addition the lesions appear lobulated with areas of signal void which represent blood vessels. We propose that the investigation of choice for diagnosing parotid haemangiomas in childhood is MRI. In a review of the literature we have been able to find only one reference to MRI in the investigation of infantile parotid haemangiomas. This was by George $e t$ al. (1991) who reported three cases investigated by MRI and concluded that the MRI appearance was sufficiently characteristic to provide a diagnosis. The advantages of MRI are as follows: firstly, the excellent picture quality and definition of tissue planes; secondly, that exposure to ionizing radiation is avoided; thirdly, that images in the axial and the coronal planes are available; fourthly, that no intravenous contrast medium is required for the MRI and finally that invasive procedures including biopsy can be avoided thus avoiding any risk of injury to the facial nerve which has a more superficial course in infancy.

The patients studied also had a parotid ultrasound scan performed and although this showed the mass as vascular it neither showed the extent of the lesion nor gave a firm diagnosis. We feel that where MRI is available ultrasound is not required. However in an infant first presenting with a parotid swelling ultrasound is a safe, simple and readily available investigative tool that will differentiate vascular, cystic and solid lesions.

Three of the patients also underwent a CT scan. This showed the haemangiomas as enhancing lesions in the parotid. A disadvantage of CT scanning is that it involves ionizing radiation. Some adult and adolescent cavernous parotid haemangiomas contain phleboliths which give a characteristic appearance on $\mathrm{X}$-ray and $\mathrm{CT}$, but these are not found in infantile haemangiomas (Nussbaum et al., 1976).

Since the 1960 s it has been recognized that many infantile haemangiomas undergo spontaneous involution and suggested management is therefore careful observation with surgery required only if there is rapid growth, facial palsy, platelet trap-

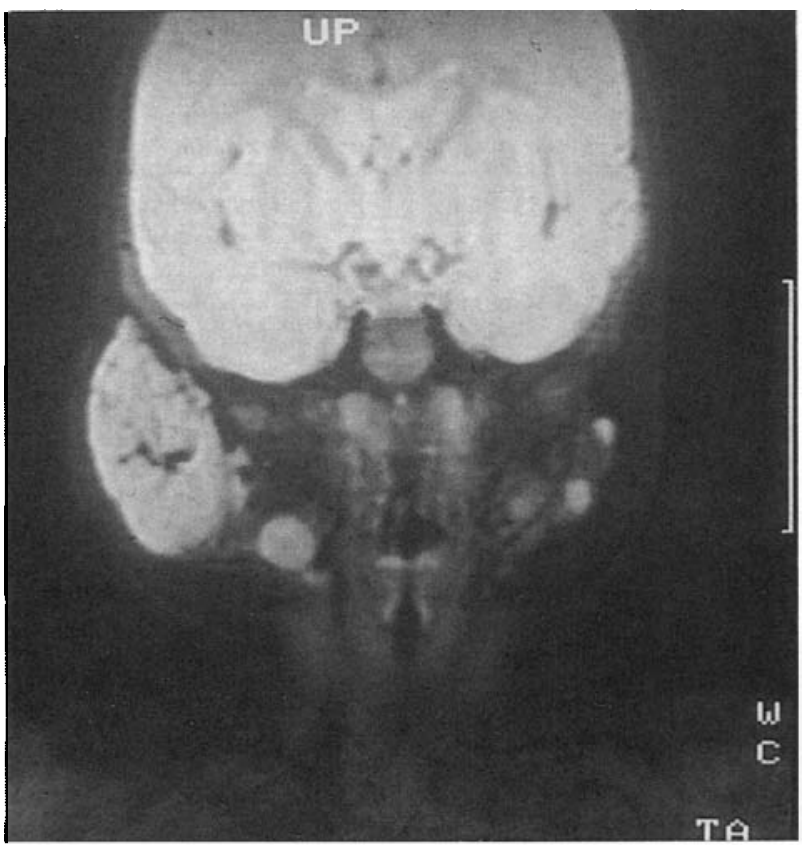

FIG. 4

MRI scan, $T_{2}$-weighted image, showing a haemangioma of the right parotid as a bright image similar in intensity to CSF.

ping or haemodynamic disturbance (Cope and Blanchard, 1965; Smith et al., 1985; Weber et al., 1990). In the group of patients studied a firm diagnosis was established by MRI and to date any invasive procedures have been avoided, except for a Tru-cut biopsy performed on one patient prior to referral.

Data regarding the natural history of parotid haemangiomas is scarce. We therefore propose to follow the progress of this cohort to elucidate this further.

\section{Conclusions}

Parotid haemangiomas are considered to be congenital tumours arising from an abnormality in the development of the intralobular vascular system of the parotid. They account for 50 per cent of parotid tumours presenting in the first year of life. They have a tendency to undergo spontaneous resolution in most cases by the age of five years and management is thus expectant. An accurate diagnosis can be made by MRI with the least risk of adverse side-effects as it is nonionizing and noninvasive. We therefore propose MRI as the investigation of choice in childhood parotid haemangiomas.

\section{Acknowledgements}

We wish to thank Mr J. N. G. Evans, Mr R. F. Gray and Mr D. M. Albert for permission to report their cases. We also wish to thank the staff of the Radiology Department and of the Department of Medical Illustration for their invaluable assistance.

\section{References}

Cope, D. A., Blanchard, C. L. (1965) Benign congenital parotid haemangiomas in infants. Laryngoscope 75: 1741-1748.

Garfinkle, T. J., Handler, S. D. (1990) Haemangiomas of the head and neck in children - a guide to management. Journal of Otolaryngology 9 (5): 439-450.

George, C. D., Ng, Y. Y., Hall-Craggs, M. A., Jones, B. M. (1991) Parotid haemangioma in infants: MR imaging at $1.5 \mathrm{~T}$. Paediatric Radiology 21 (7): 483-485.

Nussbaum, M., Tan, S., Som, M. L. (1976) Haemangiomas of the salivary glands. Laryngoscope 86: 1015-1019.

Smith, R. J. H., Wright, G. H., Katz, C. D., Atkins, J. H. (1985) Benign parotid diseases of childhood. Lanngoscope 95: 915-920.

Stenson, K. M., Mishell, J., Toriumi, D. M. (1991) Imaging case 
study of the month. Cystic hygroma of the parotid gland. Annals of Otology, Rhinology and Laryngology 100: 518-520.

Weber, T. R., Connors, R. H., Tracy, T. F., Bailey, P. V. (1990) Com-

plex haemangiomas of infants and children. Archives of Surgery 125 (8): $1017-1020$.
Address for correspondence:

Miss P. M. Huchzermeyer,

5 Cheriton Avenue.

Twyford,

Berkshire RG 10 9DB. 